\title{
New record of Calosoma (Campalita) auropunctatum (Herbst, 1784) in Latvia with notes on its occurrence in the Eastern Baltic region.
}

\author{
MAKSIMS BALALAIKINS ${ }^{1}$ \\ ARVĪDS BARŠEVSKIS ${ }^{1}$ \\ VYTAUTAS TAMUTIS ${ }^{2}$ \\ ULDIS VALAINIS ${ }^{1}$ \\ KRISTIINA AKSJUTA ${ }^{1}$ \\ ${ }^{1}$ Daugavpils University, Institute of Life Sciences \\ and Technology, Coleopterological Research Center, \\ Vienības str. 13, Daugavpils, LV-5401 Latvia \\ ${ }^{2}$ Institute of Biology and Plant Biotechnology, \\ Aleksandras Stulginskis University, Studentų str. 11, \\ Akademija, Kaunas distr., LT-53361 Lithuania

\section{Correspondence:} \\ Vytautas Tamutis \\ E-mail: dromius@yahoo.com
}

Key words: Coleoptera, Carabidae, Calosoma auropunctatum (Herbst, 1784), Latvia, faunistics
Received July 03, 2017.

Revised February 20, 2018.

Accepted June 21, 2018.

\begin{abstract}
Background and purpose: Calosoma auropunctatum (Herbst) is the species with no confirmed records in the last 150 years in the Latvian fauna. Until now, the species was considered probably extinct in this area. The species was confirmed for Latvia in 2014, during the research project devoted to biodiversity monitoring in various agrocenoses with different management systems. The aim of this paper is to clarify habitat peculiarities of the species in Latvia and discuss the possibilities of widest distribution of this species in Easter Baltic region.
\end{abstract}

Materials and methods: The study site is located in the eastern part of Latvia. The ground beetles were collected from May 2014 to August 2015 using pitfall traps, installed in 2 linear transects located at the field margin and in the central part of the field, more than $100 \mathrm{~m}$ far away from the field border.

Results: One male and three females were caught by pitfall traps during vegetation period in course of 2014-2015 years. Calosoma specimens deposited in coleopterological collections in Latvia were reviewed. Previous record of this species in Latvia based on specimen deposited in Latvian Museum of Natural History is disproved. In addition, the paper presents information on the geographical distribution and biology of the species.

Conclusions: The first proven findings of C. auropunctatum in Latvia was presented during two field season's, that suggest a presumption of occurring of small, local population of this species in territory of Latvia.

\section{INTRODUCTION}

Calosoma genus comprises quite large and diverse group of worldwide-distributed ground beetles. According to recent revision of this group, 128 species assigned to 19 subgenera are known in world (1). Only 7 of 32 species found in the Palaearctic are known in Europe $(1,2$, $3,4)$. All of them are rare, sporadically distributed in the region and most of them are granted status of protected species in many countries $(5,6,7,8,9,10,11,12)$. Adults of majority of species in Calosoma genus are well distinguished by their specific shape of the body: relatively narrow but strongly transverse pronotum, and wide, almost parallel, slightly broadened toward apex, sides of elytra. Most species of this genus are winged and in some cases they fly very well (1). Calosoma species are well known as caterpillar hunters because usually they hunt larvae of Lepi- 
doptera in the trees, shrubs or on the ground $(1,13,14)$. Therefore, some Calosoma species are important for biological control both in forestry and agriculture $(15,16$, 17). The Eastern Baltic region belongs to the area of northern part of distribution range of six Calosoma species: C. (Callisphaena) reticulatum reticulatum (Fabricius, 1787), C. (s.str.) inquisitor inquisitor (Linnaeus, 1758), C. (s.str.) sycophanta (Linnaeus, 1758) C. (Campalita) auropunctatum (Herbst, 1784), C. (Campalita) denticolle Gebler, 1833 and C. (Charmosta) investigator (Illiger, 1798) $(18,19)$. All these species are extremely rare in this region, and either listed in local Red Data books or considered as extinct $(20,21,22,19,23)$. There is no any information of occurrence of $C$. denticolle in Eastern Baltic region, but this species is mentioned in the old faunistic literature from Finland as accidentally visited species, which was collected as drift from sea shore, when eastward wind transported some material to east coast of Brännskär Island (24). However this species is listed for whole Eastern Europe (25). The occurrence of next two species $C$. investigator and C. reticulatum in the region is questionable as well. Both of them are noted for Eastern Prussia by Horion (26), and occasionally found in Sweden (19), however C. reticulatum is not listed for Eastern Europe by Kryzhanovsky et al. (25).

Three species (C. sycophanta, C. inquisitor and C.auropunctatum) were noted for whole of the Baltic region (4, 20, 25).

However, the notes on distribution of $C$. sycophanta in this region are based only on old data $(27,28,22,29,19$, 30). The most recent record of this species is known only from Lithuania (31). The most common Calosoma species in Eastern Baltic region is $C$. inquisitor. The numerous records of the species were published from Latvia, Lithuania and Kaliningrad region in recent years $(20,5 ; 21$, 32), however $C$. auropunctatum was recently known only from Lithuania $(33,34)$. Precht $(35)$ mentions the first note on presence of this species in Latvian fauna in the first catalogue of Latvian beetles, where this species was indicated for Kircholm (currently Salaspils, Riga environs). Subsequently next record of this species from Bulli, Kurzeme region in western part of Latvia (probably more than 150 years old) was mentioned by Stiprais (36) based on material of Carl Müthel's collection. Currently this collection is deposited in the Latvian Museum of Natural History. C. auropunctatum is considered as extremely rare species in Estonia, and is included in Red data book of Estonia, as extinct or probably extinct species (9). Only three, more than 80 years old records of this species are reported in this country. A knowledge on distribution of this species from Kaliningrad region is poor as well. Only three old records of this species are mentioned in literature sources: Sambian peninsula, Mechnikov (1 $19^{\text {th }}$ century) and Yantarny (the early $20^{\text {th }}$ century) (27).

New findings of Calosoma auropunctatum in Latvia focused our attention to this remarkable species and stimulate further study of its bioecology. In this paper we aimed to present new data on records of $C$. auropunctatum as well as peculiarities of its habitats in Latvia and discuss the possibilities of wider distribution of this species in Eastern Baltic region.

\section{METHODS AND RESULTS}

\section{Specifics of Latvian findings of Calosoma auropunctatum}

Calosoma auropunctatum (fig. 1.) was accidentally captured in the course of research project devoted to the longterm monitoring of status of biodiversity in various agrocenoses with different management systems, which was started in 2014. The study site is located close to the Dubna village (eastern part of Latvia) on the western slope of Latgale upland, where slightly-undulating morainic plain and gently sloping hummocks compose post-glacial landscape typical for south-eastern part Latvia (37) (fig.

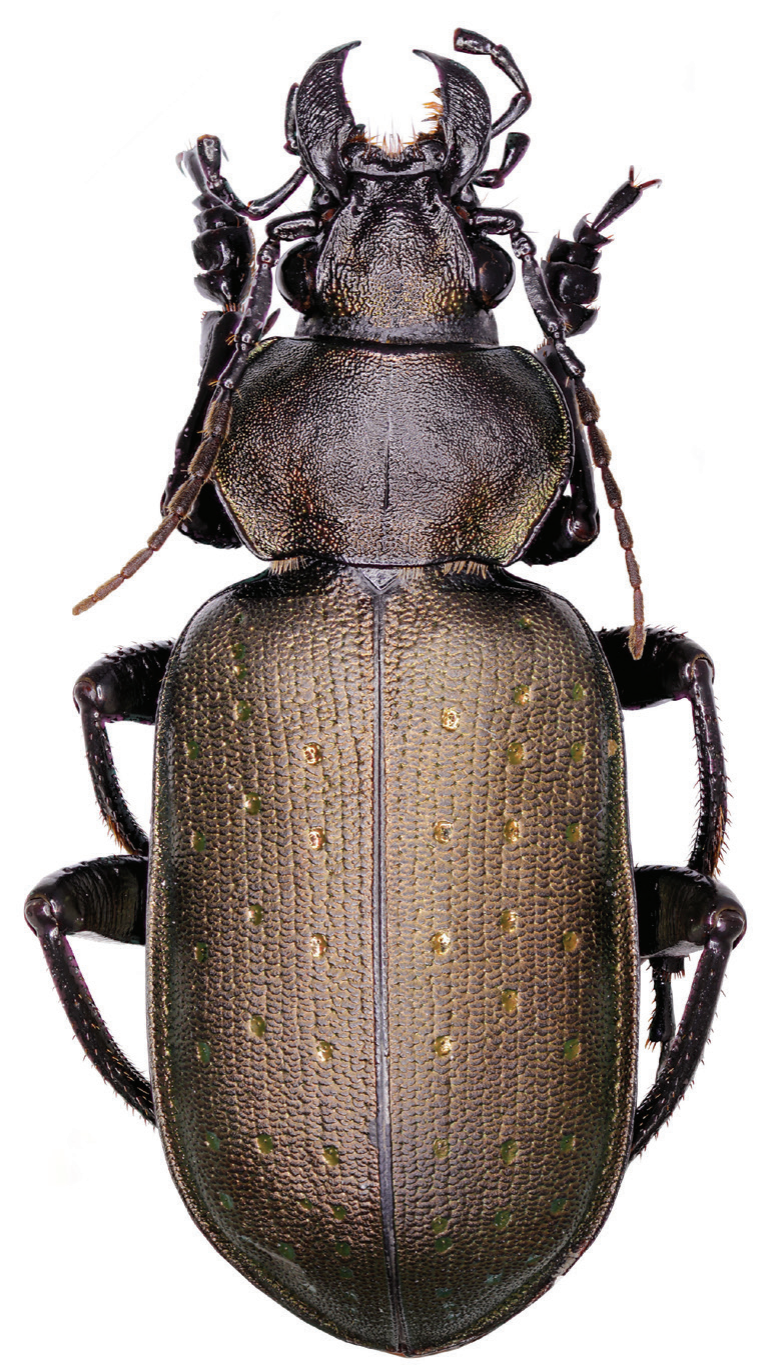

Figure 1. Calosoma auropunctatum habitus, dorsal view. 


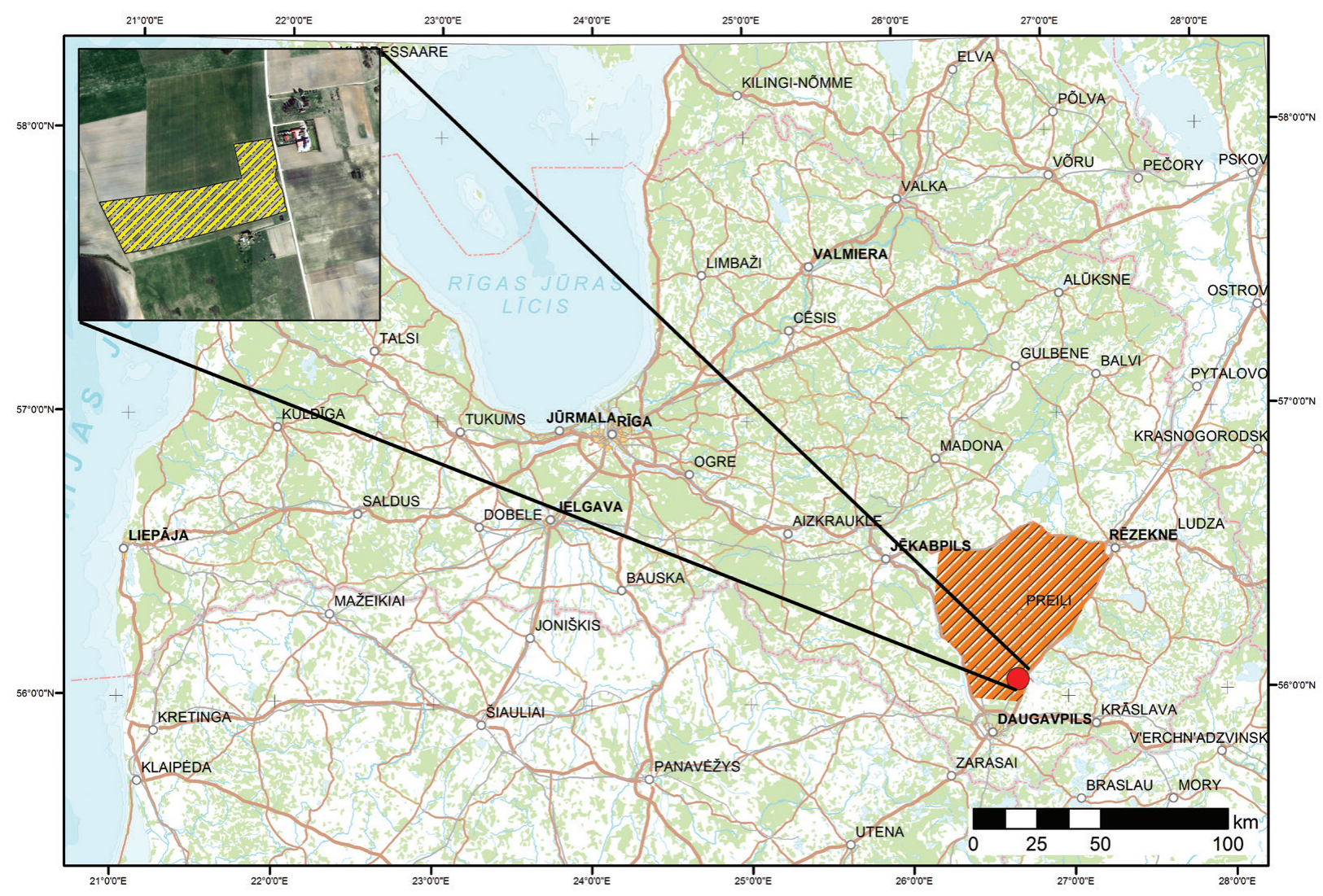

Figure 2. Map of the study area and locality of Calosoma auropunctatum in the crop field near the Dubna village.

2). Considering lithology of Quaternary deposits at the study site, glacial-till derived Stagnic Albeluvisols with stony loamy - clayey diamicton textures prevail in this part of territory (38). This field characterized as conventionally used agricultural land, which is enriched with mineral fertilizers, as well as intensive sprayed with pesticides. The spring wheat was cultivated in 2014 and winter wheat - in 2015 in this field. The field plot was about 8.3 ha, surrounded by a road from one side and other crops on another sides. The studied area is situated in mosaic agricultural landscape.

The beetles were collected using pitfall traps, which were consisted by plastic cups with $7 \mathrm{~cm}$ hole diameter and $9 \mathrm{~cm}$ high. The cups were inserted in the soil surface and filled by $50 \%$ solution of ethylene glycol to $1 / 3$ of their capacity. Altogether, we used ten pitfall traps in each plot, which were installed in two linear transects with $2 \mathrm{~m}$ intervals between each other. Five traps were installed along the field border $\left(56^{\circ} 04^{\prime} 02^{\prime \prime} \mathrm{N}, 26^{\circ} 41^{\prime} 29^{\prime \prime} \mathrm{E}\right)$ with the distance $10 \mathrm{~m}$ from the field margin in the first transect, while further five traps were arranged in the line more than $100 \mathrm{~m}$ far away from the field border $\left(56^{\circ} 03^{\prime} 58^{\prime \prime} \mathrm{N}\right.$, $26^{\circ} 41^{\prime} 17^{\prime \prime} \mathrm{E}$ ) (Fig. 3). The traps were active for two 14 days long periods during the season: 27 of May to 10 of June and from first to 15 of August in 2014 and 26 of May to
9 of June and from 29 July to 12 of August in 2015. Altogether, four specimens of $C$. auropunctatum were found in pitfall traps: three specimens ( 1 male and 2 females) were captured in the active trap period 01-15 August 2014, at the edge of the sampling plot and a single male was captured in winter wheat crop in the period 01-15 July 2015, in the centre of the field. The prepared specimens were identified by the experts of Daugavpils University to species level using various specialized keys for identification of Coleoptera and stereomicroscope Nikon SMZ 745T. The macrophotograph was taken using a single-lens reflex camera Canon EOS 60D, lens EF $100 \mathrm{~mm}$ f/2.8L IS USM.

\section{DISCUSSION}

\section{Geographic distribution}

The taxonomic status of the species has changed several times and there is no consensus on it currently. In Csiki (39) C. auropunctatum is mentioned as a variety of C. maderae, but Breuning (40) and Lindroth (41) considering it as subspecies of $C$. maderae. Most authors consider $C$. auropunctatum as distinct species $(25,42,43,44$, $45,46,47,48,49)$, and we agree with this point of view. Most remarkable difference is the opinion of Bruschi (1) 


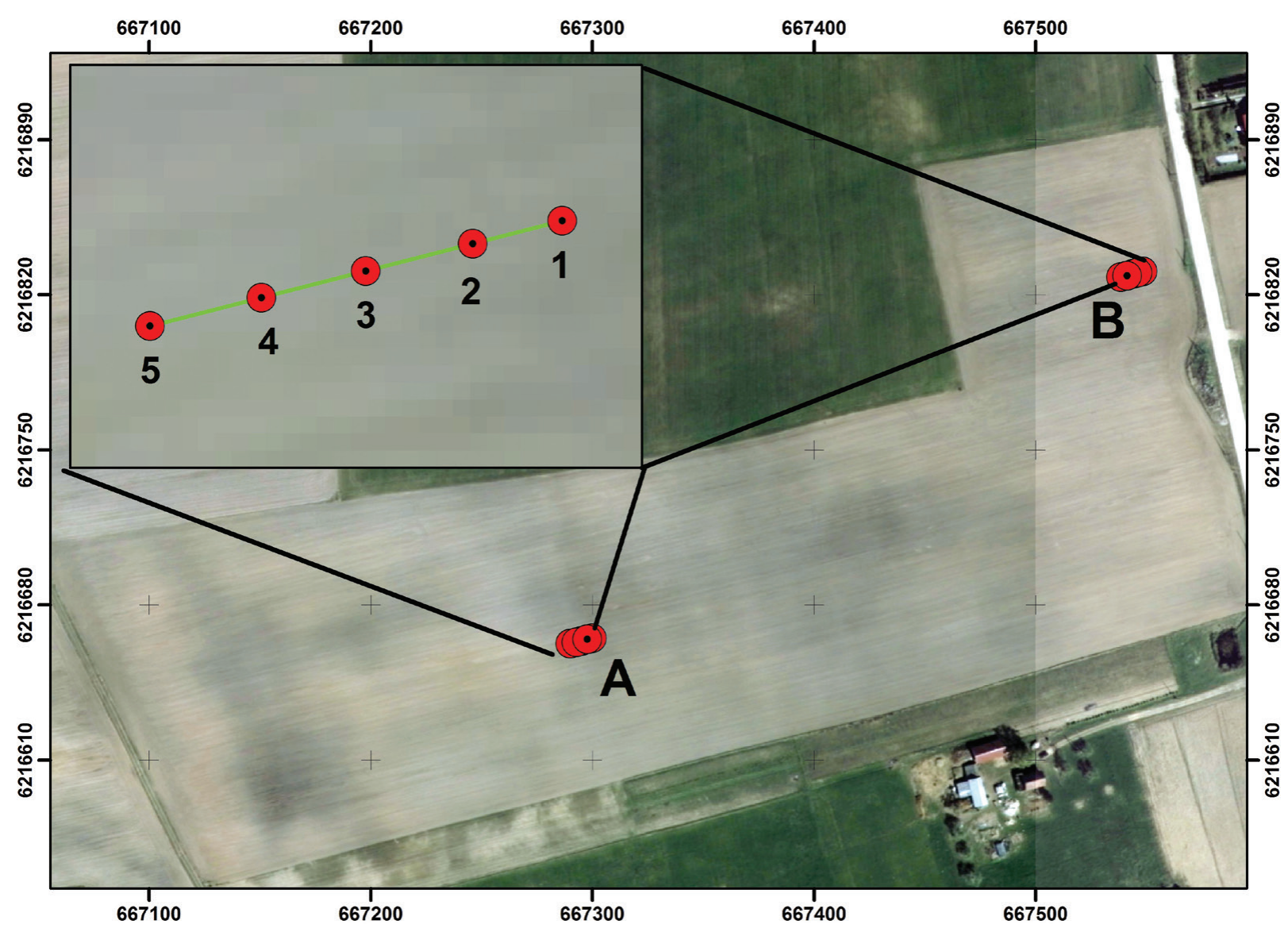

Figure 3. Transects position in the plot; $A$-in central part of the plot, $B$-along the field border.

who is considering the complex of taxa: $C$. maderae, $C$. auropunctatum, and C. indicum Hope 1831, as single $C$. maderae species including 3 subspecies: $C$. maderae maderae, C. maderae dsungaricum Gebler 1833 and C. maderae indicum. C. auropunctatum is found in a broad range of European countries, from Mediterranean countries to Scandinavia. Nevertheless, northern border of its distribution range remains unclear. The records of this species from many countries of northern Europe, such as Norway, Sweden, Estonia, northern part of European Russia (Sankt Petersburg region) are very scarce and old (19). In Denmark where $C$. auropunctatum is considered a critically endangered and has been constantly declining during $20^{\text {th }}$ century, an unknown population of the species was found in 1998, in the northern part of Jutland (49). This species is rare and sporadically distributed in the countries of central Europe, such as Germany (50), Poland (51), Slovakia and Czech Republic (52), but becomes more frequent when going to the South and East (14, 53, $54,55,56)$.

Before this study the species had not been reported from territory of modern Latvia for almost 165 years. During the study Calosoma specimen deposited in the Latvian Museum of Natural History was re-examined. It was found out that specimen previously identified erroneously as C. auropunctatum actually belongs to Calosoma (Chrysostigma) calidum (Fabricius, 1775). This species spreads through southern Canada and northern United States (13). Assuming this fact, our records of $C$. auropunctatum are the first actual findings of the species in Latvia. Of course, our data is insufficient to explain the distribution of this species at population level, but continuous findings in two season's course, suggest a presumption of presence of at least a small, local population of this species in territory of Latvia. However, we can't eliminate the possibility of the occasional migration of specimens from southern regions, maybe caused by relatively high temperatures during the summers of last decades. Moreover, the latter presumption become more persuasive considering an enormous number of previous studies on carabids in agrocenoses in various parts of Latvia without any catches of $C$. auropunctatum till 2014.

\section{Bionomy}

The knowledge on bionomy of $C$. auropunctatum is not sufficient. There are only short notes on its activity of adults and habitat preference mentioned in old literature sources (19). The diurnal activity of adults of this species 
was proved by Jørum (49). However, its presence in the light traps (57) clearly exposing their nocturnal activity and flight ability. With respect to life cycle, this species is widely represented as spring breeding species with maximum activity of adults in June $(19,56,58)$. Altogether 39 specimens of $C$. auropunctatum were captured in Lithuania since the first record of this species in the country in 1964 (59) and exclusively all of them were harvested in arable fields (partially published data in 33, 34). As much as 29 of them were caught in July, similarly to specimens from this study that were captured in July and August. $C$. auropunctatum are referred as open land species with strong preference to sandy, dry habitats with sparse vegetation $(19,49,52)$. The records of this species are from agricultural lands with different crops, but mainly from cereals in most of Europe $(53,56,58)$. Our findings confirm these preferences, but we caught this species in habitats with loamy soil type that coincide with findings in Lithuania $(33,34)$. As an accompanying species of $C$. auropunctatum we disclosed complex of another 30 species of ground beetles, where Poecilus cupreus, Pseudoophonus rufipes and Harpalus affinis were most frequent among them. However, in case of Lithuanian studies, the complex of attendant ground beetles was enriched by Pterostichus melanarius - a hygrophilic species (34). The tolerance of this species to moisture could prove also its presence in grasslands close to the rice fields $(55,60)$. These facts suggest proposition that this species tolerate more heavy and moister soils than it was regarded before. Also assuming that distribution of this species is limited to warmer regions, the temperature could be essential for its occurring in the northern parts of its distribution range where loamy soils that better accumulate temperature could be more attractive substrate.

The caterpillars, mostly Noctuidae family are presented as a main part of diet of $C$. auropunctatum (19) but it can be supplemented by eggs and larvae of Leptinotarsa decemlineata Say, 1824 as well (15). Nevertheless, more recent and precise studies of food preference of this species are still unknown.

\section{Final remarks}

Despite that $C$. auropunctatum is considerably large carabid species, and its distribution range covers most of the Europe, the data on its frequency and life cycle is not so numerous. Naturally this species inhabit regions of steppes and semi deserts and probably the spreading to the forest regions depend on development of the agriculture and creation of wide open areas. This species exclusively occurs in the agriculture landscapes and sandy dunes of seacoasts in the zone of deciduous and mixed forest in Europe. Its excellent dispersal ability seems to be very helpful to survive under high anthropogenic pressure and readjust to various agrobiocenoses. Varvara et al. (56) reports on occurrence of this species not only in wheat, maize, sugar beet, sunflowers, potatoes crops, but also in vineyards or even apple orchards. Moreover Tamutis et al. (34) and our current discoveries show tolerance of this species to even conventionally managed fields. Assuming that the main factor limiting the spread of this species to northern regions is the temperature, the spread of this species to the northern regions could be indicative of environmental and species composition changes taking place, as a consequence of global warming. Hence, this species could be useful as an indicator of global warming in Northern Europe and further monitoring could give important information that are associated with global warming processes.

Acknowledgements: We are very grateful to Alexander Anichtchenko (Daugavpils University) for identification of Calosoma specimens. The research was part of ongoing evaluation of the Latvian Rural Development Plan 2007-2013 and financed by European Union and Latvian government, under the Technical Assistance. The research was carried out with financial support from the Latvian State Institute of Agrarian Economics.

\section{REFERENCES}

1. BRUSCHI S 2013 Calosoma of the World (Coleoptera, Carabidae). Natura Edizioni Scientifiche di Alfonso Iorio, Bologna, p 314

2. MÜLLER - MOTZFELD G 2004 Bd. 2 Adephaga 1: Carabidae (Laufkäfer). - In: FREUDE H, HARDE K W, LOHSE G A, KLAUSNITZER B: Die Käfer Mitteleuropas. Spektrum-Verlag, Heidelberg/Berlin, 2. Aufl age. p 521

3. GUEORGUIEV B V 2007 Annotated catalogue of the carabid beetles of Albania (Coleoptera: Carabidae). Pensoft, Sofia-Moscow, p 243

4. SILFVERBERG H 2010 Enumeratio renovata Coleopterorum Fennoscandiae, Daniae et Baltiae. Sablbergia, 16(2): 1-144

5. ALEKSEEV V I 2010 Threatened beetle species (Coleoptera) on the territory of the Kaliningrad region, including those listed in the Red Data book of Lithuania. Acta Zoologica Lituanica, 20(1): 3-11 DOI 10.2478/v10043-010-0001-z. https://doi.org/10.2478/ v10043-010-0001-z

6. DZ U 2011 Rozporządzenie Ministra Środowiska z dnia 12 października 2011r. w sprawie ochrony gatunkowej zwierząt. Dziennik Ustaw, 237: 1419

7. GÄRDENFORS U (ed) 2010 Rödlistade arter i Sverige 2010 - the 2010. Art Databanken, SLU, Uppsala

8. GÜRLICH S, SUIKAT R, ZIEGLER W 2011 Rote Liste der in Schleswig-Holstein gefährdeten Käfer. Hrsg.: Ministerium für Landwirtschaft, Umwelt und ländliche Räume des Landes Schleswig-Holstein, Kiel, 1: 126

9. MARTIN M, LUIG J, SÜDA I, TIMM H. 2008. Selgrootud loomad. In: Eesti Punane Raamat, Eesti Teaduste Akadeemia Looduskaitsekomisjon, Tartu: 16-20

10. RAŠOMAVIČIUS V (ed) 2007 Lietuvos raudonoji knyga. Lututé, Kaunas, p 800

11. STOLTZE M, PIHL S (ed) 1998 Rødliste 1997 over planter og dyr i Danmark. Miljøog Energiministeriet. Danmarks Miljøundersøgelser og Skovog Naturstyrelsen p 220

12. SPURIS Z (ed) 1998 Bezmugurkaulnieki. Latvijas Sarkanā grāmata, 4 sēj., Rìga, p 388 
13. BURGESS A F, COLLINS C W 1917 The genus Calosoma: including studies of seasonal histories, habits and economic importance of American species north of Mexico and of several introduced species//Bull. US Dept Agr Div Entomol, 417: 1-124

14. KRYZHANOVSKIY O L 1962 The caterpillar hunters Calosoma Web. and Callisthenes Fisch-W. (Coleoptera, Carabidae) in the U.S.S.R. Entomol. Obozr., 41(1): 163-181

15. GROZEA I, CĂRĂBEȚ A, CHIRIȚĂ R, BADEA A M, PRUNAR F, ADAM F 2007 Biological control trials of invasive species from maize agroecosystems by exploitation of indigenous natural enemies. Lucrări ştiințifice Facultatea de Agricultură, 39 (1): 407-410

16. KANAT M, ÖZBOLAT M 2006 Mass production and release of Calosoma sycophanta L. (Coleoptera: Carabidae) used against the pine processionary moth, Thaumetopoea pityocampa (Schiff.) (Lepidoptera: Thaumetopoeidae), in biological control. Turkish J. Zool., 30: 181-185

17. WACHMANN E, PLATEN R, BARNDT D 1995 Laufkafer, Beobachtung, Lebenweise [Beetles, observation of life]. Naturbuch Verlag, Leipzig, p 295

18. BOUSQUET Y, BĽEZINA B, DAVIES A, FARKAČ J, SMETANA A 2003 Carabidae: Carabinae, Carabini. In: Löbl I, Smetana A. (Eds). Catalogue of Palaearctic Coleoptera, Vol.1: Archostemata - Myxophaga - Adephaga. Apollo Books, Stenstrup: 118-201

19. LINDROTH C H 1949 Die Fennoscandischen Carabidae 1. Specieller Teil. Wettergren \& Kerbers Förlag, Göterborg, p 710

20. ALEKSEEV V I 2008 Check-list of the ground beetles (Coleoptera, Carabidae) of Kaliningrad region. Acta Biologica Universitatis Daugavpiliensis, 8 (2): 153-191

21. BARŠEVSKIS A 2003 Latvijas skrejvaboles (Coleoptera, Carabidae, Trachypachidae, Rhysodidae). Baltic Institute of Coleopterology, Daugavpils, p 264

22. HABERMAN H 1968 Eesti jooksiklased. Kirjastus Valgus, Tallinn, p 598

23. PILECKIS S, MONSEVIČIUS V 1995 Lietuvos fauna. Vabalai 1 Mokslas, Vilnius, p 304

24. STORÅ R 1935 Calosoma denticollis och Orneodes hexadactyla, nya för Finland. Memoranda Societas Pro Fauna et Flora Fennica, 12: 60

25. KRYZHANOVSKIY O L, BELOUSOV I A, KABAK I I, KATAEV B M, MAKAROV K V, SHILENKOV V G 1995 A Checklist of the Ground-Beetles of Russia and Adjacent Lands (Insecta, Coleoptera, Carabidae). Pensoft Publishers, Sofia-Moscow, p 271

26. HORION A 1941 Faunistik der deutschen Käfer. Band I: Adephaga - Caraboidea. Krefeld, p 464

27. BERCIO H, FOLWACZNY BR 1979 Verzeichnis der Käfer Preussens. Parzeller \& Co, Fulda p 37

28. GROSCHKE J 1805 Merkwürdigkeiten aus dem Tierreich. In: Derschau E, Keyserlingk P (eds) Beschreibungen der Provinz Kurland. Mitau: 119-176

29. LENTZ F L 1879 Catalog der Preussischen Käfer. Beiträge zur Naturkunde Preussens 4: 1-64

30. SEIDLITZ G 1887-1891 Fauna Baltica. Die Käfer (Coleoptera) der Ostseeprovinzen Russlands. Zweite neu bearbeitete Auflage mit 1 Tafel. Königsberg: $12+$ LVI p. $192+818$

31. PILECKIS S, MONSEVIČIUS V 198265 new and 3 very rare for the Lithuanian SSR Coleoptera species found in 1971-1980. In: Jonaitis V (ed). New and Rare for the Lithuanian SSR Insect Species.Reports and Accounts of 1981. Lithuanian Entomological Society, Vilnius: $12-30$

32. BARŠEVSKIS A, CIBUL,SKIS R, SHAVRIN A, ANICHTCHENKO A, VALAINIS U, BALALAIKINS M, VOROBJEVA I, LITVINCEVA J 2012 Faunistic records of the beetles (Hexapoda: Coleoptera) in Latvia. 4. Acta Biol. Univ. Daugavp., 12(4): 85-117
33. TAMUTIS V 2000 Carabid beetles species diversity and abundance in some agrobiocenoses. In: Metspalu L, Mitt S (eds) Proceedings of the International Conference Tartu, Estonia September 28-29, 2000. "Development of environmentally friendly plant protection in the Baltic region”.Tartu University Press, Tartu: 200-204

34. TAMUTIS V, ŽIOGAS A, ŠALUCHAITE் A, KAZLAUSKAITE் S, AMŠIEJUS A 2007 Epigeic beetle (Coleoptera) communities in summer barley agrocenoses. Baltic Journal of Coleopterology, 7 (1): 83-98

35. PRECHT K 1818 Verzeichnis der bis jetzt, vornehmlich in der Umgegend von Riga und im Rigischen Kreise bekannt gewordenen und systematisch bestimmten käferartigen Insecten (Coleoptera Linnaei, Eleutherata Fabricii). D. Müller, Riga, p 39

36. STIPRAIS M. 1984. Skrejvaboles Kārḷa Mìteḷa kolekcijā Rīgā. Latvijas Entomologs, 27: 32-38

37. ZELČS V, MARKOTS A, NARTIŠS M, SAKS T 2011 Chapter 18: Pleistocene Glaciations in Latvia. In: Ehlers J, Gibbard P L, Hughes P D (eds.), Quaternary glaciations - extent and chronology. A closer look. Developments in Quaternary Science, 15. Elsevier: 221-229

38. JUŠK,EVIČS V, SKREBELS J 2003 Quaternary deposits. In: Āboltiņš O, Brangulis A J (eds), Geological Map of Latvia. Scale 1:200,000. Sheet 34-Jēkabpils. Sheet 24-Daugavpils. Explanatory Text and Maps. State Geological Survey, Rīga: 10-29

39. CSIKI E 1927 Carabidae, Carabinae I. In Coleopterorum Catalogus auspiciis et auxilio W. Junk editus a S. Schenkling, Berlin 91, p 553

40. BREUNING S 1927 Monographie der Gattung Calosoma (Coleoptera: Carabidae) 1.Teil. Koleopterologische Rundschau, 13(4/5): $129-232$

41. LINDROTH C H 1985 The Carabidae (Coleoptera) of Fennoscandia and Denmark. Fauna Entomologica Scandinavica, Vol. 1. Brill, Leiden-Copenhagen, p 226

42. GANGLBAUER L 1892 Die Käfer von Mitteleuropa. I. Band. Familienreihe Caraboidea 55 Textfiguren. Verlag von Carl Gerolds Sohn., Wien, p 557

43. APFELBECK V. 1904. Die Käferfauna der Balkanhalbinsel mit Berücksichtigung Klein-Asiens und der Insel Kreta.(1). Friedländer u. Sohn Verlag, Berlin, p 422

44. JEANNEL R 1940 Les Calosomes [Calosomes] (Coleoptera, Carabidae). Mémoires du Muséum National d'Histoire Naturelle (Paris) $13: 1-240$

45. GUEORGUIEV V B, GUEORGUIEV B V 1995 Catalogue of the ground-beetles of Bulgaria (Coleoptera: Carabidae). Pensoft Publishers, Sofia-Moscow, p 279

46. NECULISEANU Z Z, MATALIN A V 2000 A Catalogue of the Ground-Beetles of the Republic of Moldovia (Insecta, Coleoptera: Carabidae). Pensoft Publishers, Sofia - Moscow p 164

47. BRANDMAYER P, ZETTO T, PIZZOLOTTO R 2005 I Coleotteri Carabidi per la valutazione ambientale e la conservazione della biodiversità. APAT, Agenzia per la protezione dell'ambiente e per iservizi tecnici, p 240

48. CASALE A, VIGNA TAGLIANTI A 1999 Caraboid beetles of Anatolia and their biogeographical significance (Coleoptera, Carabidae). Biogeografica 20: 277-407

49. JØRUM P. 1999. En population af strandpupperover, Calosoma maderae (Fabricius, 1775) i det nordlige Jylland (Coleoptera, Carabidae). Ent. Meddr., 67(2): 39-45

50. KIELHORN K H 2005 Rote Liste und Gesamtartenliste der Laufkäfer (Coleoptera: Carabidae) von Berlin. In: der Landesbeauftragte für naturschutz und landschaftspflege/ senatsverwaltung für stadtentwicklung (Hrsg.): Rote Listen der gefährdeten Pflanzen und Tiere von Berlin. CD-ROM 
51. HURUK S 2002 Biegaczowate (Coleoptera, Carabidae) w jednorocznych uprawach rolnych na glebach bielicowych (Carabid beetles (Coleoptera, Carabidae) in annual crops on podzolic soils). Rocznik Świętokrzyski. Ser. B - Nauki Przyrodnicze 28: 39-52

52. HU゚RKA K 1996 Carabidae of the Czech and Slovak Republics. Illustrated key. Kabourek, Zlin, p. 565

53. ALEKSANDROWICZ O 2014 Ground beetles (Coleoptera, Carabidae) west of the forest zone of the Russian Plain. Fauna, zoogeography, ecology, faunogenesis. Lambert Academic Publishing, Saarbrücken, p 456

54. BRYGADYRENKO V V 2003 Fauna of ground beetles (Coleoptera, Carabidae) of Dnipropetrovsk region. Problems of Ecology and Environmental Protection in a Technogenic Region 3: 78-88

55. PILON N, CARDARELLI E, BOGLIANI G 2013 Ground beetles (Coleoptera: Carabidae) of rice field banks and restored habitats in an agricultural area of the Po Plain (Lombardy, Italy). Biodivers. Data J., 1: e972. https://doi.org/10.3897/BDJ.1.e972
56. VARVARA M, CHIMISLIU C ŠUSTEK Z 2012 Distribution and abundance of Calosoma auropunctatum Herbst, 1784 (Coleoptera: Carabidae) in some agricultural crops in Romania, 1977-2010. Muzeul Olteniei Craiova. Oltenia. Studii şi Comunicări. Ştiințele Naturii, 28: 79-90

57. MATALIN A V 2003 Variations in flight ability with sex and age in ground beetles (Coleoptera, Carabidae) of south-western Moldova. Pedobiologia, 47(4): 311-319.

https://doi.org/10.1078/0031-4056-00195

58. KHABIBULINA N R, SUKHODOLSKAYA R A 2014 Ground beetles (Coleoptera, Carabidae) assemblages in agricultural landscapes. Euroasian Entomological Journal 31(4): 379-387

59. PILECKIS S 1968 Naujos ir mažai žinomos vabalų (Coleoptera) rūšys Lietuvos TSR faunoje. $L \check{Z} \breve{U} A$ mokslo darbai, 14(2): 43-48

60. GHAHARI H, JEDRYCZKOWSKI W B, KESDEK M, OSTOVAN H, TABARI M 2009 Ground beetles (Coleoptera: Carbidae) from rice fields and surrounding grasslands in Northern Iran. Journal of Biological Conservation, 23(2): 105-109 